\title{
HYDROGEN-MINERAL REACTIONS AND THEIR APPLICATION TO THE REMOVAL OF IRON FROM SPODUMENE
}

\author{
E. WM. Heinrich \\ Department of Geology, and Mineralogy. The University of Michigan. \\ Ann Arbor, MI 48109. U.S.A. \\ and \\ C. A. SAlottI \\ Department of Geology, University of Wisconsin-Milwaukee. \\ Milwaukee, W1 53201, U.S.A. \\ and \\ A. A. GiardinI \\ Department of Geology. University of Georgia. Athens, GA 30601, U.S.A. \\ (Received 25 October 1977)

\begin{abstract}
Abatret-Peamatitic deposits contain three distinctly different types of spoduneae: (1) Phenocrystic spodumene in unzoned pegmatites. This type is high-iron spodumene, with $\mathrm{Fe}_{2} \mathrm{O}_{3}=0.6-0.9 \%$. (2) Zonal spodumene. Large laths in central zones; it contrins $0.01-0.03 \% \mathrm{Fe}_{2} \mathrm{O}_{3}$. (3) Spodumene plus quartz ageregates pseudomorphous after petalize; $\mathrm{Fe}_{2} \mathrm{O}_{3}=0.007-0.03 \%$. Only Type 1 generally occurs in deposits sufficiently large and uniform to be economically exploitable. Two processes are presently available for iron removal. Both require initial inversion of the (a) spodumene to its $\beta$-dimorph: (1) The chlorine process in which the isomorphous iron is converted to iron chloride and (2) The hydrocen process in which the $\mathrm{Fe}^{3+}$ ion is reduced to metallic iron.

Hydrogen-mineral reactions, such as hydrogen-carbonate reactions, are potential sources of lime, methane and iron. They also are inportant for the beneficiation of such ceramic materials as spodumene and feldspar.
\end{abstract}

\section{INTRODUCTION}

The utilization of spodumene as raw material for the Li-Al-Si type of glass ceramics requires that the spodumene be essentially iron-free. Most of those spodumenes that are initially of sufficient purity occur either (1) in deposits that are not amenable to large-scale mining methods or (2) in deposits that are politically unavailable (e.g. Bikita, Rhodesia). The large quantities of spodumene in the King's Mountain type of pegmatite require beneficiation in order to diminish their iron contents to render them suitable for glass-ceramic purposes. The purposes of this paper are to (1) describe the several genetic types of spodumene and their iron contents and (2) describe the hydrogen method for iron removal.

\section{CRYSTAL CHEMISTRY OF SPODUMENE}

Spodumene is structurally a member of the pyroxene group characterized by linkage of $\mathrm{SiO}_{3}$ tetrahedra by sharing two out of four corners to form continuous chains of the composition $\left(\mathrm{SiO}_{3}\right)_{n}$. Spodumene is structurally similar to diopside, with the $c$ parameters of the two essentially identical, but with $a$ and $b$ of spodumene significantly smaller, in response to the coupled substitution:

$\begin{array}{ll}\text { spodumene } & \text { diopside } \\ \mathrm{Li}^{+} \mathrm{Al}^{3+} & \mathrm{Ca}^{2+} \mathrm{Mg}^{2+} \\ \text { (smaller) } & \text { (larger) }\end{array}$

The substitution of these smaller ions results in a closer packing of the $\mathrm{SiO}_{4}$ tetrahedra, thus reducing the number of minor-element ions that the structure can tolerate: larger in diopside, smaller in spodumene.

The minor elements in spodumene are mainly $\mathrm{Na}, \mathrm{Fe}, \mathrm{Mn}$. Many analyses also show 
$\mathrm{K}_{2} \mathrm{O}=0 . \mathrm{x}-\mathrm{x} .0 \%$, but this stems mainly from minute inclusions of muscovite. Some $\mathrm{Na}$ may replace $\mathrm{Li}$, but it is likely that most of the $\mathrm{Na}$ is in solution or occurs as daughter salts in the abundant brine-filled inclusions that characterize spodumene (Heinrich, pers. obs.).'

Two colored gem varieties of spodumene are recognized: hiddenite (deep green) and kunzite (lilac). Hiddenites owe their green color to the substitution $\mathrm{Cr}^{3+}-\mathrm{Al}^{3+}$, and kunzites are lilac because of the substitution $\mathrm{Mn}^{3+}-\mathrm{Al}^{3+}$, in those spodumenes that have a low $\mathrm{Fe} / \mathrm{Mn}$ ratio. ${ }^{2}$ Manganese acts as a significant chromophore only if not masked by the more powerful chromophore $\mathrm{Fe}$, just as in the pink muscovites. ${ }^{3}$ Modern analyses of spodumenes show $\mathrm{FeO}=0.00-0.36 \%, \mathrm{Fe}_{2} \mathrm{O}_{3}=0.02-1.58 \%{ }^{4}$ In order to determine the amounts of structurally contained (isomorphous) iron, a number of spodumene samples were very carefully purified and checked for homogeneity via X-ray diffraction analysis. The results are presented in Table 1.

Three distinct paragenetic types of spodumene can be identified in pegmatites: ${ }^{5}$

(1) Phenocrystic spodumene in essentially unzoned pegmatites of the "King's Mountain type". These laths, usually less than a foot long, commonly are greenish and contain essential $\mathrm{Fe}^{3+}$ in substitution for $\mathrm{Al}^{3+}$, usually in the range of $\mathrm{Fe}_{2} \mathrm{O}_{3}=0.6-0.9 \%$.

(2) Zonal spodumene, commonly as large laths that occur in intermediate zones and cores of well-zoned pegmatites. This spodumene is low in iron $\left(\mathrm{Fe}_{2} \mathrm{O}_{3}=0.01-0.03 \%\right)$. It may contain significant manganese (x.0-0.x\%), and whereas most is white, some is pink or lilac (kunzite).

(3) Secondary spodumene. Produced by the isochemical decomposition of petalite:

$$
\begin{aligned}
& \text { petalite } \rightarrow \text { spodumene }+2 \text { quartz, } \\
& \text { LiAlSi }_{4} \mathrm{O}_{10} \rightarrow \mathrm{LiAlSi}_{2} \mathrm{O}_{6}+2 \mathrm{SiO}_{2} .
\end{aligned}
$$

This spodumene is relatively fine-grained; commonly the aggregate retains the crystal form and basal leavage of the parent petalite. It is white and has very low iron ( $\mathrm{Fe}_{2} \mathrm{O}_{3}=0.007-0.03 \%$ ), because of the low-iron content of the parent petalite.

Spodumene is or has been produced from all three types of deposits. Type 1 deposits can be mined en masse, and the spodumene is recoverable by beneficiation. Type 2 deposits are of limited dimensions and must be mined selectively; the spodumene is recovered by handsorting. Type 3 deposits are rare; only two are presently economic-Bernic Lake, Manitoba and Bikita, Rhodesia. At Bernic Lake, Cérný and Ferguson ${ }^{6}$ distinguish three types of spodumene:

Type A, tabular aggregates of fibrous spodumene intergrown with quartz, clearly pseudomorphous after petalite which constitute $90 \%$ of all spodumene in the pegmatite. Type B. laths up to $1.5 \mathrm{~m}$ long, in the intermediate core-margin zone, not associated with petalite, and identified as primary zonal spodumene. Type $\mathrm{C}$, fibrous to columnar spodumene in quartz, but not tabular (may be secondary and perhaps recrystallized).

Most of the spodumene recovered by flotation at Bernic Lake is Type 3 spodumene (Type A of Cerny and Ferguson). ${ }^{6}$

At Bikita, all of the spodumene is Type 3 (after petalite) and is recovered by hand-sorting.

Examples of pegmatites and pegmatite districts with Type 1 spodumene include: King's Mountain, N.C.; Blandford-Goshen area, Mass.; Peg Claims, Rockland, Maine; PreissacLacorne district, Quebec; and Volta Grande, Minas Gerais, Brazil. Examples of Type 2 spodumene deposits are: Mt. Mica district, Maine; Branchville, Conn.; the Black Hills, S.D.; Harding Mine, N.M.; Wickenburg district, Ariz.; San Luis in Cordoba and Sierra de Ancasti in Catamasca, both in Argentina. Examples of Type 3 spodumene deposits (spodumene secondary after petalite) are, in addition to Bernic Lake and Bikita: Varuträsk, Sweden, and Karibib, South West Africa.

From this survey of spodumene types, their geology and their distribution, it becomes apparent that in order to insure a large supply of low-iron glass-ceramic spodumene, spodumene of Type 1 must be mined, concentrated and treated to remove its isomorphous iron.

\section{IRON REMOVAL PROCESSES}

Isomorphous (structurally contained) iron can be removed from spodumene by chlorine or hydrogen extraction.

Spodumene occurs in two structural modifications: low-temperature or $\alpha$-spodumene, which is the form of all naturally occurring spodumene; and high-temperature, or $\beta$-spodumene. Spodumene inverts to its high-temperature polymorph rapidly above $900^{\circ} \mathrm{C}$. Fine grinding and 


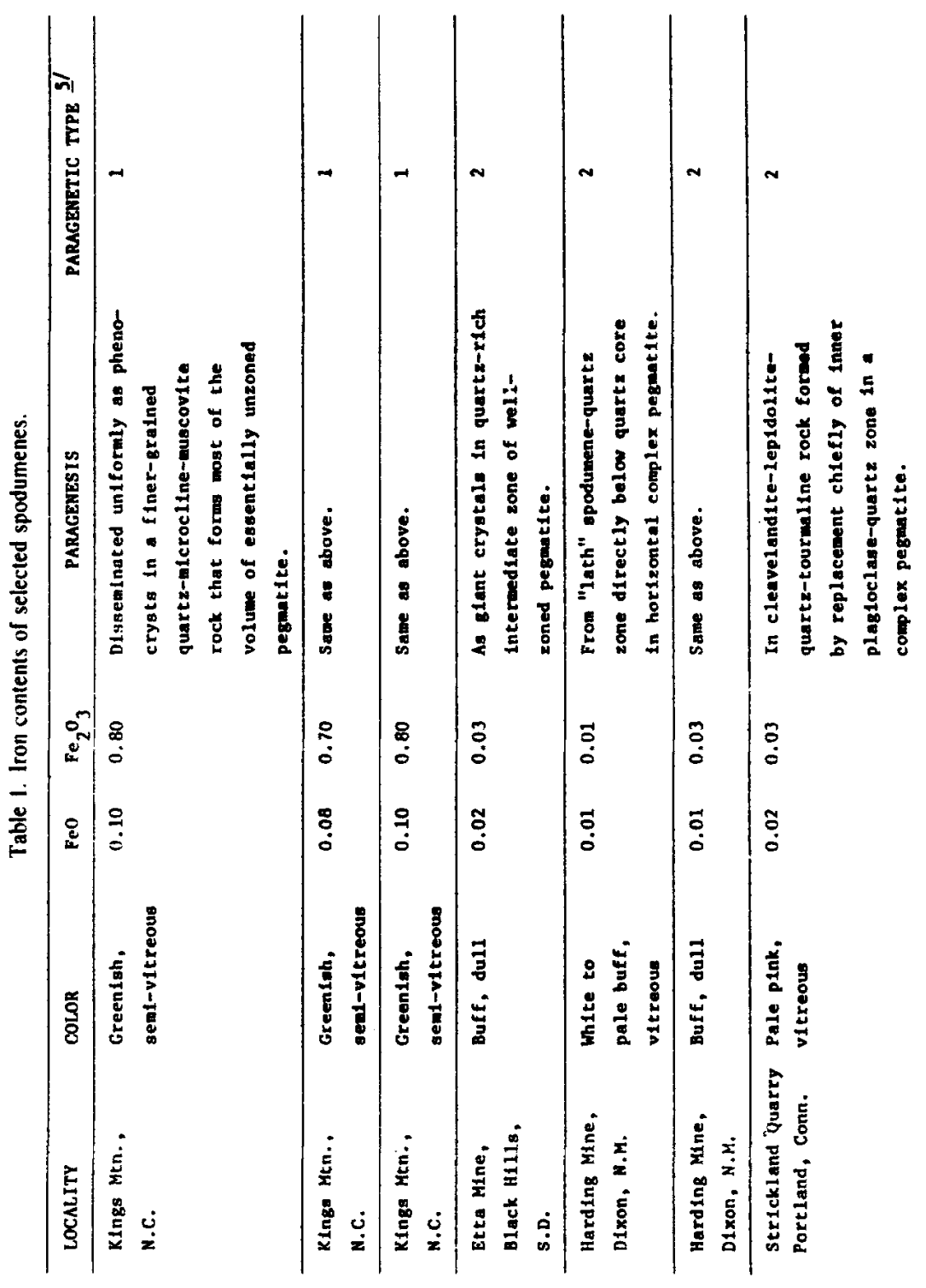




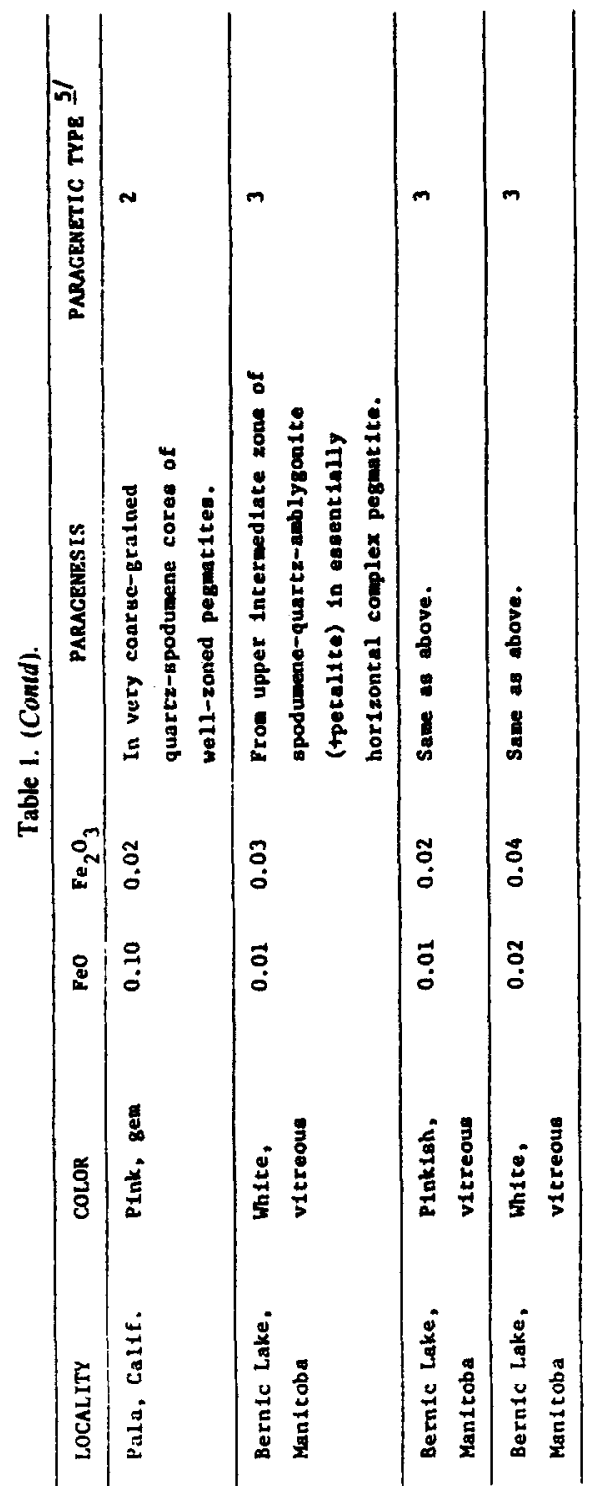


prolonged heating will also produce the transformation at about $700^{\circ} \mathrm{C}$. The inversion temperature is reduced to $500^{\circ} \mathrm{C}$ at a pressure of $10,000 \mathrm{lb} / \mathrm{in}^{2}$. The transformation is monotropic and $\alpha$-spodumene cannot be derived from its $\beta$-form. Beta-spodumene is tetragonal ( $\alpha$ is monoclinic) and has a markedly reduced coefficient of thermal expansion. In the inversion of the single-chain structure, cross-linkage develops in the silica tetrahedra to form a spiral chain-type structure, namely, the keatite-type structure. The $c$ dimension contracts, whereas a expands, thus "tightening" the tetrahedra. In the keatite structure the $\mathrm{Al}^{3+}$ ions become interstitial, carrying with them the $\mathrm{Fe}^{3+}$ ions. The lithium is confined to the spiral tunnels formed by the inversion. A $30 \%$ increase in volume accompanies the inversion. Initially the $\beta$-spodumene forms very small crystallites, which, however, sinter rapidly to larger aggregates.

Thus, in effect, the inversion prepares the spodumene for iron extraction, in forming a more open type structure and reducing the strength of the $\mathrm{Al}^{3+}$ and $\mathrm{Fe}^{3+}$ bonds.

In the chlorine process employed by Foote Mineral Company, inverted $\beta$-spodumene is heated to about $300^{\circ} \mathrm{C}$ at which temperature chlorine is introduced into the pressurized system.? Care must be exercised in controlling the chlorination temperature, for with higher temperatures lithium also is removed, and at lower temperatures insufficient iron is extracted. By this process, ceramic-grade spodumene concentrates with $0.67 \% \mathrm{Fe}_{2} \mathrm{O}_{3}$ are beneficiated to $\beta$ spodumene with only $0.075 \% \mathrm{Fe}_{2} \mathrm{O}_{3}$.

The hydrogen process stems from the results of a series of experiments on hydrogenmineral reactions begun in 1966 by Salotti and Giardini. ${ }^{-10}$ In 1971 a patent was obtained for this process involving the hydrogen-carbonates reaction," and in 1972 a patent was issued for the hydrogen-spodumene reaction process. ${ }^{12}$

\section{HYDROGEN-MINERAL REACTIONS}

\section{Hydrogen-calcite}

In the calcite-hydrogen system. from reactions on calcite fragments of $40-60$ mesh, between 535 and $870^{\circ} \mathrm{C}$, and 200 and 8000 psi of initial hydrogen, the following compounds were obtained: solid $\mathrm{CaO} ; \mathrm{Ca}(\mathrm{OH})_{2}$; graphite; and amorphous carbon. Gaseous $\mathrm{CH}_{4} ; \mathrm{C}_{2} \mathrm{H}_{6} ; \mathrm{CO}, \mathrm{CO}_{2}$; and $\mathrm{H}_{2} \mathrm{O}$ also formed.

Below its dissociation temperature $\mathrm{Ca}(\mathrm{OH})_{2}$ is the stable solid reaction phase. In runs allowed to cool to room temperature under the reaction gases, $\mathrm{C} 2(\mathrm{OH})_{2}$ is always. present. In experiments run above the dissociation temperature of $\mathrm{Ca}(\mathrm{OH})_{2}, \mathrm{CaO}$ is present if the reaction gases are replaced with helium at the operating temperature. Analyses of the reaction gases indicate that water is the oxygenated product. Simplified equations for the reactions are the following:

(A) $\mathrm{CaCO}_{3}+4 \mathrm{H}_{2}=\mathrm{CaO}+\mathrm{CH}_{4}+2 \mathrm{H}_{2} \mathrm{O}$,

(B) $\mathrm{CaCO}_{3}+4 \mathrm{H}_{2}=\mathrm{Ca}(\mathrm{OH})_{2}+\mathrm{CH}_{4}+\mathrm{H}_{2} \mathrm{O}$.

\section{Hydrogen-dolomite}

Dolomite and hydrogen were reacted under the following conditions: (1) fragment size 40-60 mesh; (2) $520-835^{\circ} \mathrm{C}$; (3) $200-5000 \mathrm{psi}$ initial hydrogen pressure; and (4) experiments lasting between 2 and $12 \mathrm{hr}$. Solid reactants observed include: $\mathrm{CaCO}_{3}$ (calcite); $\mathrm{Ca}(\mathrm{OH})_{2} ; \mathrm{CaO}$; non-crystalline $\mathrm{Mg}(\mathrm{OH})_{2}$; elemental carbon or graphite. Gas analyses show: $\mathrm{CH}_{4} ; \mathrm{C}_{2} \mathrm{H}_{6} ; \mathrm{CO}$; and $\mathrm{CO}_{2}$. Water is the oxygenated product from all of the experiments.

In the thermal dissociation of dolomite under the vapor pressure of the system, the reaction occurs in two stages. The first dissociation, stoichiometrically simplified, is as follows:

$$
\mathrm{CaMg}\left(\mathrm{CO}_{3}\right)+\Delta=\mathrm{MgO}+\mathrm{CaCO}_{3}+\mathrm{CO}_{2} \text {. }
$$

With increasing temperature, the remaining calcite decomposes to lime and carbon dioxide, with the exact dissociation temperature determined by the carbon dioxide pressure. If the $\mathrm{P}_{\mathrm{CO}_{2}}$ never exceeds $100 \mathrm{~mm}$, dolomite decomposes in a single stage dissociation as follows:

$$
\mathrm{CaMg}\left(\mathrm{CO}_{3}\right)+\Delta=\mathrm{MgO}+\mathrm{CaO}+2 \mathrm{CO}_{2} \text {. }
$$

In the dolomite-hydrogen reaction, $\mathrm{CO}_{2}$ is not a reaction product under most of the experimental conditions and appears only as a minor component of the reaction gases at lower hydrogen pressures. It likely is incidental to the main reaction of direct methanation. 
The second stage is represented by the following equation:

$$
4 \mathrm{H}_{2}+\mathrm{CaMg}\left(\mathrm{CO}_{3}\right)_{2}=\mathrm{CaCO}_{3}+\mathrm{Mg}(\mathrm{OH})_{2}+\mathrm{CH}_{4}+\mathrm{H}_{2} \mathrm{O} \text {. }
$$

\section{Hydrogen-siderite}

The reaction between $40-60$ mesh siderite fragments and hydrogen is more complex than the preceding calcite-hydrogen and dolomite-hydrogen reactions. The runs were between 400 to $605^{\circ} \mathrm{C}$ and 2000 to $5000 \mathrm{psi}\left(\mathrm{H}_{2}\right)$, all for $4 \mathrm{hr}$. A "thermal soak" under helium was used in each case to bring the bomb up to temperature before venting and replacing helium for the reaction gas. Because of the low temperature for thermal dissociation of siderite, in those experiments at higher temperatures some siderite undoubtedly decomposed and the decomposition gas, presumably $\mathrm{CO}_{2}$, was expelled along with the helium. For this reason the mole percentages of gaseous hydrocarbons determined in the reaction gas for these experiments are minimum values.

The reaction gases include appreciable methane and lesser amounts of ethane, propane and butane. Water was present in all of the experiments.

The appearance of propane and butane can best be understood by considering the thermal stability of these hydrocarbons. The temperature necessary for siderite to react at an appreciable rate is low enough so that ethane, propane and butane are thermally stable. There is no direct evidence to indicate how these methane homologues form. Indirect evidence suggests that they do not form from methane. Some of the higher-temperature calcite and dolomite hydrogen runs were allowed to cool slowly under the reaction gases (methane, water, hydrogen), and the higher hydrocarbons did not form.

Inorganic hydrocarbons up to and including butane form directly in carbonate mineralhydrogen reactions at temperatures as low as $400^{\circ} \mathrm{C}$. The experimental evidence indicates that hydrocarbons form directly from a mineral surface-hydrogen reaction rather than from a subsequent reaction between generated gases and hydrogen. In general, the reaction rate is rapid at temperatures well below the "in-air" calcination temperatures of the carbonate minerals.

\section{Hydrogen-silicate reactions}

Hydrogen-silicate reactions differ significantly from hydrogen-carbonate reactions inasmuch as the mineral species, although modified, are not decomposed and remain structurally essentially unchanged after the reactions. Among the minerals that have been treated are: (1) olivine. (2) feldspar, (3) spodumene. In all the experiments the reactions involve the reduction of iron. either as $\mathrm{Fe}^{2+}$ or $\mathrm{Fe}^{3+}$, or both, to elemental $(\alpha)$ iron. The iron originally occurs as the substitutions $\mathrm{Mg}^{2+}-\mathrm{Fe}^{2+}, \mathrm{Al}^{3+}-\mathrm{Fe}^{3+}$. $\mathrm{Fe}^{3+}$ also may be present as microscopic inclusions of hematite, as in the red potash-rich feldspars. The $\alpha$-iron migrates to cleavage or fracture surfaces of the mineral particles whence it can be loosened mechanically and removed magnetically.

Green dunitic olivine, containing several per cent $\mathrm{FeO}$, can be converted to snow-white, iron-free olivine. Reddish iron-rich feldspars, containing tiny hematite platelets and some isomorphous $\mathrm{Fe}^{3+}$ as well, can be beneficiated to the extent that total remaining iron as $\mathrm{Fe}_{2} \mathrm{O}_{3}$, is $\sim 0.0 \times \%$.

For spodumene the process is as follows:

(1) Grinding to $40-60$ mesh.

(2) Heating and inversion to $\beta$-spodumene.

(3) Reacting $\beta$-spodumene at various temperatures and pressures (of hydrogen) in a sealed oxygen-free system.

Examples of the results are listed in Table 2.

The following reaction applies:

$$
\mathrm{Fe}^{3+}+3 / 2 \mathrm{H}_{2}+3 \mathrm{O}^{2-} \rightarrow \mathrm{Fe}+3 \mathrm{H}_{2} \mathrm{O} .
$$

A vacant site is left at former ferric iron positions in the structure. $\mathrm{X}$-ray examination of the spodumene before and after treatment reveals that the peak spacing are not shifted but the intensity peaks change slightly with respect to one another, supporting this mechanistic 
Table 2. Examples of reacting $\beta$-spodumene in a sealed oxygen-free system.

\begin{tabular}{|c|c|c|c|}
\hline$T, 0^{*}$ & $p, p=1$ & Tise, ninute. & I Te renoved \\
\hline 400 & 100 & 60 & 29.6 \\
\hline 400 & 100 & 10 & 30.3 \\
\hline 400 & 100 & 300 & 28.4 \\
\hline 400 & 1500 & 10 & 25.5 \\
\hline 700 & 100 & 180 & 46.5 \\
\hline 700 & 100 & 10 & 30.8 \\
\hline 800 & 100 & 10 & 45.4 \\
\hline 800 & 100 & 20 & 59.4 \\
\hline 900 & 100 & 10 & 78.8 \\
\hline
\end{tabular}

interpretation of the process. It can be seen that temperature and time are the controlling factors in the process, with the time required at the higher temperatures to obtain high percentage of iron removal being relatively short in any event. At $400^{\circ} \mathrm{C}, 25-30 \%$ of the iron is extracted; at $700^{\circ} \mathrm{C} 31-46 \%$; at $800^{\circ} \mathrm{C} 59 \%$; and at $900^{\circ} \mathrm{C} 79 \%$. The magnitude of the hydrogen pressure is not significant so long as it is adequate to insure an intimate contact of hydrogen with the mineral particles and the $\mathrm{P}_{\mathrm{H}_{2}} / \mathrm{P}_{\mathrm{H}_{2} \mathrm{O}}$ remains high. For this reason, a pressure above atmospheric such as on the order of $50 \mathrm{psi}$, is adequate, and for the above reasons a temperature in the range of $700-1200^{\circ} \mathrm{C}$ is preferred for a time period of several minutes. In the above examples, the pressure vessel was flushed with helium to remove air, but it should be understood that the flushing step could be substituted by evacuation. or, if flushing is desired, a less expensive gas such as argon could be substituted for helium. Hydrogen is an excellent heat exchanger. "Cool" unused hydrogen could be flushed through the vessel to lower the temperature of the solid produced below the in-air oxidation temperature. This also would heat the hydrogen to be used as a reactant. Any cheap gas $\left(\mathrm{N}_{2}\right.$, etc.) or even vacuum could be used during the cooling stage.

The $\alpha$-iron coats the surfaces of the $\beta$-spodumene particles. It can be loosened ultrasonically and removed magnetically. There is no lithium loss, even at highest operating temperatures tested. No toxic reactants are employed, nor are any toxic products produced.

\section{CONCLUSIONS}

Hydrogen-mineral reactions have important implications in several areas of mineral technology:

(1) For hydrogen-carbonate reactions, the potential economic products are lime and methane.

(2) The hydrogen-siderite reactions offer means of reducing sideritic ores by utilizing low-grade and protores and of producing methane and higher alkanes as byproducts.

(3) The hydrogen-silicate reactions are a way of removing contaminating Fe from a variety of silicate species, including feldspars and spodumene, enabling their utilization as ceramic materials.

\section{REFERENCES}

1. V. V. Gordienko and G. E. Kalenchuk, Zap. Uses. Min. Obskch. 95, 169 (1966).

2. E. W. Clafiy, Am. Mineral. 3\%, 919 (1953).

3. E. Wm. Heinrich and A. A. Levinson. Am. Mineral. 38. 25 (1953).

4. E. Wm. Heinrich, Indian J. Earth Sci. 2,18 (1975).

5. E. Wm. Heinrich, U.S. G. S. Prof. Paper 1015, 50 (1976).

6. P. Cerny and R. B. Ferguson, Canad. Mineral. 11, 660 (1972).

7. L. W. Richardson and J. Bishwick, Paper presented, NW Ohio Sect. Am. Ceram. Soc. Ann. Symp.. Toledo, Ohio, 22 Jan. 1968.

8. A. A. Giardini, C. A. Salotti and J. Lakner, Science 159, 317 (1968).

9. A. A. Giardini and C. A. Salotti, Am. Mineral. S4, 1151 (1969).

10. C. A. Salotti, E. Wm. Heinrich and A. A. Giardini, Proc. 6th Forum Geol. Indust. Minerals, Mich. Geol. Survey Misc. 1, 48 (1970).

11. C. A. Salotti, U.S. Patent No. 3,558,724 (1971).

12. C. A. Salotti, U.S. Patent No. 3,694,189 (1972). 